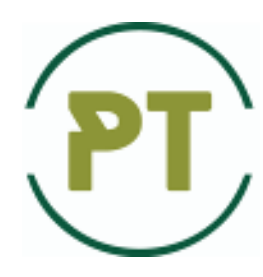

Problems of Tribology, V. 26, No 2/100-2021, 34-40

Problems of Tribology

Website: http://tribology.khnu.km.ua/index.php/ProbTrib

E-mail: tribosenator@gmail.com

DOI: https://doi.org/10.31891/2079-1372-2021-100-2-34-40

\title{
Dependences of changes in the structural viscosity of oil films on the friction surface with fullerene compositions
}

\author{
A.G. Kravtsov \\ Kharkiv Petro Vasylenko National Technical University of Agriculture, Kharkiv, Ukraine \\ E-mail: kravcov@gmail.com
}

\begin{abstract}
In this work, the physical phenomenon of the formation of an oil film containing fullerenes was further developed, on the friction surface of tribosystems, which, in contrast to the known ones, takes into account the structural viscosity and structure of the formed film under the action of the electrostatic field of the friction surface. An increase in load significantly increases the structural viscosity of the gel structure, $13-20$ times. The concentration of fullerenes in the base lubricant does not significantly affect the dynamic viscosity of aggregates in the composition of the liquid and the structure of the gel.

An increase in the tribological properties of the base lubricant medium reduces the value of the structural viscosity of the gel on the friction surface by a factor of 3 . At the same time, the concentration of fullerenes in the range of $0.5-1.5 \%$ does not have a large effect on these indicators. This phenomenon can be explained by the presence or absence of an additive package in the base lubricating medium. For those oils where the additive package is absent or present in a small amount $E_{\text {spec }}=(1,8 \ldots 3,6) \cdot 10^{14} \mathrm{~J} / \mathrm{m}^{3}$, the introduction of a fullerene composition promotes the formation of clusters and micelles, which increase the structural viscosity and, consequently, form a film on the friction surface in the form of a gel structure. Conversely, if fullerenes are introduced into a base oil that contains a large and balanced additive package, where tribological properties are high $\left.E_{\text {spec }}\right\rangle(3,6-7,2) \cdot 10^{14} \mathrm{~J} / \mathrm{m}^{3}$, interaction at the molecular level does not occur. Fullerenes to a lesser extent will form stable aggregates in the form of micelles.

The effect of reducing the coefficient of friction, equal to $96 \%$, is typical for low and medium loads of operation of tribosystems and base lubricants with average values of tribological properties. With increasing loads or tribological properties of base oils, the effect of the use of fullerenes decreases.

Keywords: fullerenes, oil film, fullerene compositions, structural viscosity, sol structure, gel structure, electrostatic field of the friction surface, dynamic viscosity.

\section{Introduction}

The use of fullerenes as anti-wear, extreme pressure and antifriction additives to technical liquid lubricants gives an ambiguous answer about their effectiveness. There is a direction where fullerenes, in the form of nanopowders, are directly introduced into the lubricant and the direction, where pre-dispersion of fullerenes is used in solvents, for example, vegetable high oleic oils, and then the introduction of such compositions into technical oils. According to the authors of the work [1], this use of fullerenes gives a better positive effect than the addition of fullerenes in the form of nanopowders to lubricants.

The general structural feature of liquid lubricants in the presence of fullerenes in them is that clusters and micelles are formed in the volume of the liquid. Based on the findings [2] it can be argued that a viscous liquid can be considered as a continuous dispersion medium, and clusters and micelles as a dispersion phase. Fullerene molecules interacting with each other and oleic acid molecules of vegetable oil form aggregates, and the viscous liquid medium becomes structured.
\end{abstract}




\section{Literature review}

Author of the work [3] claims that structured fluids form aggregates in the form of doublets or chains, chains can form a continuous grid. The interaction of aggregates in the volume of fluid is expressed in the formation of sufficiently strong compounds, primarily of coagulation origin. Anisometric units are able to rotate when the layers of liquid are shifted. According to the author of the work [3] rheological properties of suspensions due to the volume concentration of the dispersed phase, the magnitude of the forces of interaction between aggregates and particles and the structure of the formed aggregates. The author considers Brownian motion of particles to be the main factors influencing the process of aggregate formation, gravitational and repulsive forces that occur between particles, hydrodynamic interaction between particles.

In our opinion, when considering the processes of friction and wear, when the friction surfaces accumulate electrostatic charge [1], it is necessary to consider the forces of electrostatic interaction between the units of the dispersed phase and the friction surface. It should be borne in mind that the concentration of units in the field of electrostatic forces of the friction surface will be greater than at a distance from the surface where the field does not act.

According to the conclusions of the work [2] units of the dispersed phase, combined by external electrostatic forces into a continuous grid (frame) on the friction surface, acquire the properties of a "solid".

Insignificant external load forms elastic deformation of a skeleton. At high enough loads, the frame collapses and the individual units disconnect. In this case, according to the authors [2], individual units (clusters and micelles of fullerenes) can form a rotational motion between the friction surfaces. When such an interaction mechanism occurs, the viscosity of the fluid gradually decreases [2].

The above conclusion is accepted by us as a working hypothesis of reduction of friction forces in tribosestopics in the presence of a dispersed phase in the lubricant, which will be further confirmed by theoretical models and experimentally.

The presence in the volume of the lubricant of the dispersed phase in the form of clusters and micelles requires, along with the total dynamic viscosity of the liquid, to consider the "structural viscosity". This concept was introduced in the work [4]. The use of the concept of "structural viscosity" allows to take into account not only the dynamic viscosity of the liquid, but also the dynamic viscosity of the units that are in the volume of the liquid, taking into account the shear rate.

The authors of the work [5] provides an overview of the literature on lubricants with added nanoparticles. The effect of nanoparticles on the tribotechnical characteristics of oils is analyzed. It is noted in the work that the use of nanoadditives to lubricants leads to an increase in the viscosity of the base medium, high bearing capacity of the interface, reducing the coefficient of friction, increasing wear resistance.

In work [6] theoretical studies of changes in the structural viscosity of oil films on the friction surface with fullerene compositions in the field of action of electrostatic forces of the friction surface and the base lubricant are presented. Based on the working hypothesis, it was theoretically established that for a thin oil film located in the field of action of electrostatic forces of the friction surface, the structural dynamic viscosity of the lubricant must be considered, which at the friction surface has gel structures, and as the electrostatic forces from the friction surface decrease, the gel structure transforms into a sol structure.

It is shown that the value of the structural viscosity of the considered aggregates is comparable with the viscosity of polymers or bitumen. In this case, the viscosity of the gel structure is four orders of magnitude higher than the viscosity of the sol structure. An increase in the concentration of fullerenes leads to an increase in the dynamic viscosity of aggregates.

It has been shown theoretically that the structure of the oil film, which corresponds to the structure of the gel, belongs to the class of non-Newtonian liquids. With an increase in the slip rate, the dynamic viscosity of such structures decreases by a factor of 4 , which is explained by the destruction of micelle clusters and the appearance of rotational motions of elastic flocks. It is assumed that this will lead to a decrease in the value of the coefficient of friction. It is shown that for the gel structure, the concentration of fullerenes in the bulk of the base lubricant does not have a large effect on the structural viscosity. Conversely, for the structure of a sol, the concentration of fullerenes has a significant effect on the value of the structural dynamic viscosity.

\section{Purpose}

The aim of this work is to obtain theoretical dependences of the effect on the structural viscosity of oil films containing fullerene compositions in the field of action of electrostatic forces of the friction surface, operating factors, such as load, tribological properties of the base lubricant.

\section{Methods}

In developing a microreological model for the formation of a thin film of lubricant on the friction surface under the action of electrostatic forces, the following assumptions were made. 
1. The dispersion of clusters and micelles in the volume of liquid lubricant outside the action of the electrostatic field of the friction surface is taken as the structure of the sol [4]. In this structure, stresses are perceived by a viscous liquid medium and transmitted to elastic units. This structure has viscoelastic properties.

2. The dispersion of clusters and micelles near the friction surface (in the field of electrostatic forces), take the structure of the gel [6], where between the micelles and the friction surface there are forces of electrostatic interaction, which contribute to the formation of a framework of units, the cavities between which are filled with a viscous fluid. This structure has elastic and viscous properties. Intermicellar forces can relax, respectively, the structure behaves like Maxwell's body [4]. In such a structure, stresses are perceived by the elastic elements of the units and transmitted to a viscous liquid medium.

3. A tribosystem was chosen for modeling: a movable triboelement steel 40H (HRC52); fixed triboelement Br.AZh 9-4 (HB 100); friction area of the movable triboelement $F_{f \mathrm{rm}}=0,0003 \mathrm{~m}^{2}$, fixed $F_{f \mathrm{f} \mathrm{f}}=0,00015 \mathrm{~m}^{2} ;$ ringto-ring interface. The sliding speed was constant and amounted to $v_{s l}=0,5 \mathrm{~m} / \mathrm{s}$; load varied within $N=600 \ldots 1800$ $\mathrm{N}$; the tribological properties of the lubricating medium varied within $E_{\text {spec }}=(1,8 \ldots 7,2) \cdot 10^{14} \mathrm{~J} / \mathrm{m}^{3}$.

\section{Results}

Based on the expressions that are given in the work [6], the structural viscosity of the sol $\mu_{s}$ and gel $\mu_{g}$ can be determined:

$$
\begin{aligned}
& \mu_{s}=k_{l} \mu_{l}+k_{f} \mu_{K}, \mathrm{~Pa} \cdot \mathrm{s}, \\
& \mu_{g}=k_{l} \mu_{l}+k_{f} \mu_{M}, \mathrm{~Pa} \cdot \mathrm{s},
\end{aligned}
$$

where $\mu_{s}$ and $\mu_{g}$ - structural dynamic viscosity of sol and gel, which are formed under the action of the electrostatic force field of friction surfaces, dimension $\mathrm{Pa} \cdot \mathrm{s}$;

$k_{l}, k_{f}$-dimensionless coefficients that take into account the mass concentration of fullerenes per unit of lubricant outside the field of action of electrostatic forces and on the friction surface, in the field of action of electrostatic forces;

$\mu_{l}$ - dynamic viscosity of the base lubricant, dimension Pa·s;

$\mu_{K}, \mu_{M}-$ dynamic viscosity of aggregates of structures consisting of Kelvin bodies and Maxwell bodies, dimension $\mathrm{Pa} \cdot \mathrm{s}[7]$.

Calculation formulas for determining the above parameters are presented in the work [6].

Dependences of changes in the structural dynamic viscosity of a thin oil film on the friction surface, in the field of action of electrostatic forces, which consists of aggregates of Maxwell's bodies $\mu_{M}$ and gel structures $\mu_{g}$, are shown in fig. 1 and fig. 2 .

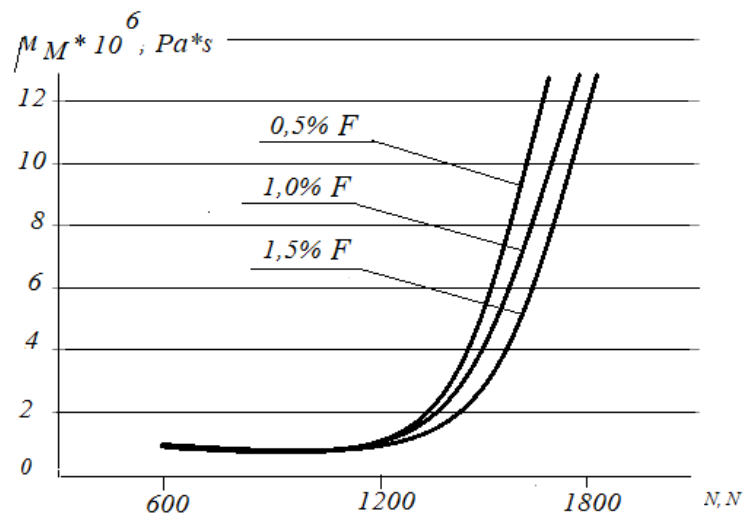

Fig. 1. Dependences of changes in the structural viscosity of aggregates consisting of Maxwell's bodies on the load and concentration of fullerenes 


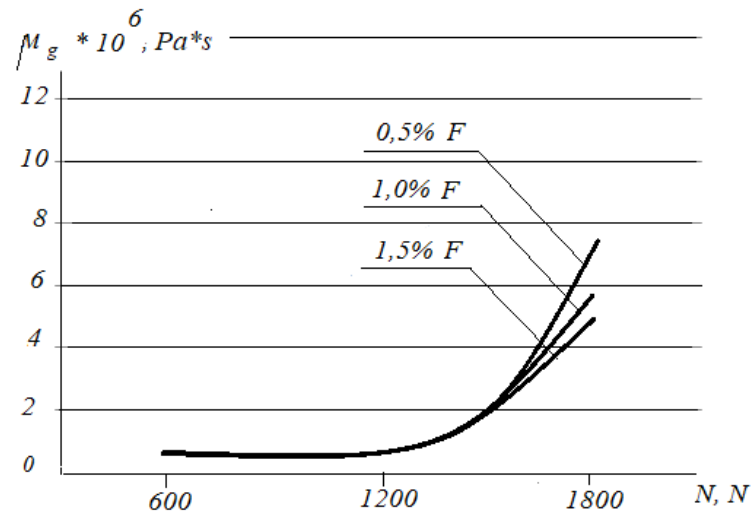

Fig. 2. Dependences of the change in the dynamic viscosity of the gel structure on the load and the concentration of fullerenes

The nature of the change in the presented dependencies allows us to draw the following conclusions.

As follows from the presented dependences in fig. 1 and fig. 2 an increase in load significantly increases the structural viscosity of aggregates in the form of a Maxwell body, fig. 1 and the viscosity of the gel structure, 13 - 20 times, fig. 2. The concentration of fullerenes in the base lubricant does not significantly affect the dynamic viscosity of aggregates in the composition of the liquid and the structure of the gel. Such an increase in the dynamic viscosity of the gel structure can be explained by the squeezing out of a viscous liquid under load and, thereby, a decrease in its content in the gel structure.

The general conclusion for the presented dependences is that with an increase in the load, the structure of the oil film on the friction surface in the presence of fullerene compositions acquires the properties of an "elastic solid". In this case, the concentration of fullerenes in the basic lubricating medium does not play a large role.

Modeling the nature of the change in the structural viscosity in the field of action of electrostatic forces of the friction surface with a change in the tribological properties of the base lubricant medium and the concentration of fullerenes in this medium is shown in fig. 3 and 4.

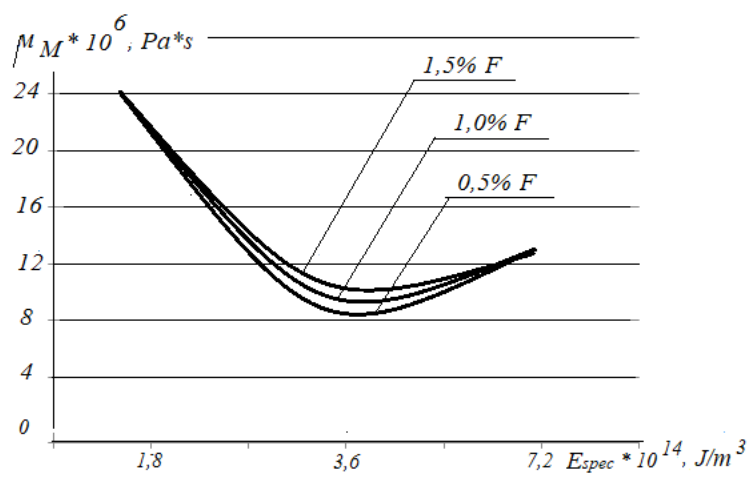

Fig. 3. Dependences of changes in the structural viscosity of aggregates consisting of Maxwell bodies on the tribological properties of the lubricating medium and the concentration of fullerenes

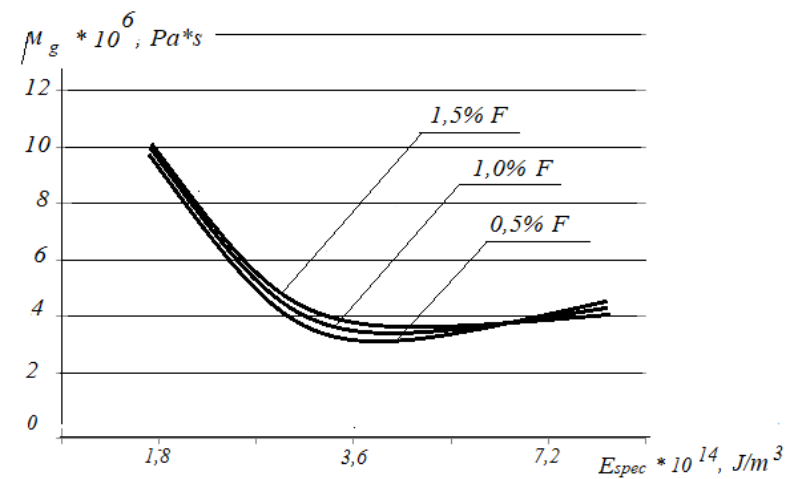

Fig. 4. Dependences of the change in the dynamic viscosity of the gel structure on the tribological properties of the lubricating medium and the concentration of fullerenes 
The following lubricating media were used in the modeling: hydraulic oil MGP-10, $E_{\text {spec }}=1,8 \cdot 10^{14} \mathrm{~J} / \mathrm{m}^{3}$; motor oil $\mathrm{M}-10 \mathrm{G}_{2} \mathrm{k}, \quad E_{\text {spec }}=3,6 \cdot 10^{14} \mathrm{~J} / \mathrm{m}^{3}$; transmission oil VALVOLINE GL-5, $E_{\text {spec }}=7,2 \cdot 10^{14} \mathrm{~J} / \mathrm{m}^{3}$. Determination of the tribological properties of lubricating media as a parameter $E_{s p e c}$ - specific work of wear, presented in the work [8].

As follows from the presented dependences, an increase in the tribological properties of the lubricating medium reduces the value of the structural viscosity of aggregates in the form of Maxwell bodies, fig. 3 and the structural viscosity of the gel on the friction surface by a factor of 3, fig. 4 . At the same time, the concentration of fullerenes in the range of $0.5-1.5 \%$ does not have a large effect on these indicators. In our opinion, this phenomenon can be explained by the presence or absence of an additive package in the base lubricating medium. For those oils where the additive package is absent or present in an insignificant amount $E_{\text {spec }}=(1,8 \ldots 3,6) \cdot 10^{14}$ $\mathrm{J} / \mathrm{m}^{3}$, the introduction of a fullerene composition promotes the formation of clusters and micelles, which increase the structural viscosity, and consequently, form a film on the friction surface in the form of a gel structure. Conversely, if fullerenes are introduced into a base oil that contains a large and balanced additive package, where tribological properties are high $\left.E_{\text {spec }}\right\rangle(3,6-7,2) \cdot 10^{14} \mathrm{~J} / \mathrm{m}^{3}$, interaction at the molecular level does not occur. Fullerenes to a lesser extent will form stable aggregates in the form of micelles.

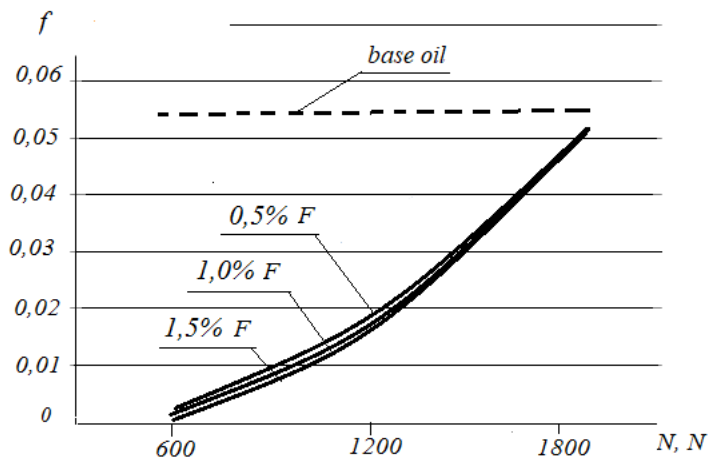

Fig. 5. Dependences of the change in the friction coefficient of the tribosystem on the load and the concentration of fullerenes

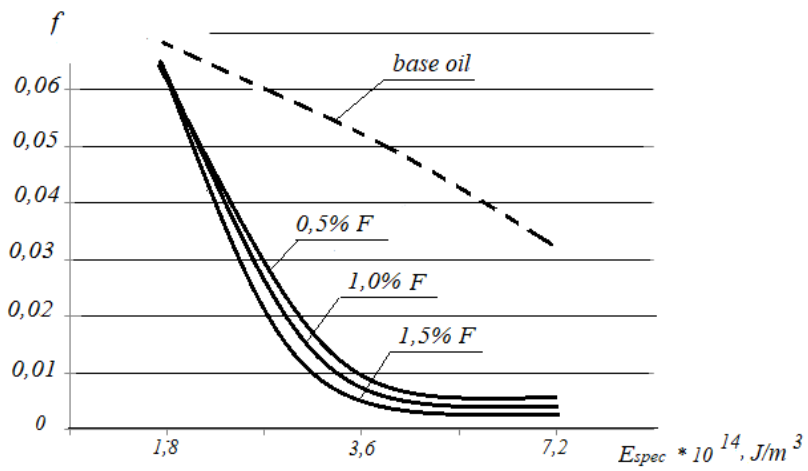

Fig. 6. Dependences of the change in the friction coefficient of the tribosystem on the tribological properties

of the lubricating medium and the concentration of fullerenes

The change in the structural dynamic viscosity of a thin oil film on the friction surface made it possible to theoretically obtain the dependence of the change in the friction coefficient on the change in the load on the tribosystem and the concentration of fullerenes in the base oil, which is shown in fig. 5. The dashed line shows the change in the friction coefficient when the tribosystem operates on base oil, $M-10 \mathrm{G}_{2} \mathrm{k}$, solid lines in the presence of different concentrations of fullerenes in the base oil.

Analysis of the presented dependences allows us to conclude that the maximum effect when using fullerenes is observed at low and medium loads. The effect of reducing the coefficient of friction at $N=600 \mathrm{~N}$ equal to $96 \%$, at $N=1200 \mathrm{~N}-66 \%$. At maximum load $N=1800 \mathrm{~N}$, the effect is $7,2 \%$. At the same time, a change in the concentration of fullerenes in the range from $0.5 \%$ to $1.5 \%$ affects the change in the coefficient of friction in the range of $3-5 \%$.

Theoretically, the dependences of the change in the friction coefficient on the tribological properties of the base lubricating medium were obtained $E_{\text {spec }}$ and the concentration of fullerenes in this medium, which are shown 
in fig. 6. The dashed curve corresponds to the change in the friction coefficient of the tribosystem on base oils without the use of fullerenes, solid lines for oils with different concentrations of fullerenes.

Analysis of the presented dependences allows us to assert that the introduction of fullerenes into hydraulic oils with low values of tribological properties $E_{\text {spec }}=1,8 \cdot 10^{14} \mathrm{~J} / \mathrm{m}^{3}$ reduces the coefficient of friction by $4 \%$. The maximum effect of reducing the coefficient of friction, equal to $83-98 \%$, is typical for oils with $E_{\text {spec }}=3,6 \cdot 10^{14}$ $\mathrm{J} / \mathrm{m}^{3}$. These are mid-quality oils, which include engine oil $\mathrm{M}-10 \mathrm{G}_{2} \mathrm{k}$.

The use of base oils with $E_{\text {spec }}>3,6 \cdot 10^{14} \mathrm{~J} / \mathrm{m}^{3}$ does not lead to an increase in the effect of reducing the friction coefficient from the use of fullerenes, the friction coefficient remains constant. In this case, the magnitude of the change in the coefficient of friction when using different concentrations of fullerenes is within $13 \%$.

Based on the above theoretical studies, it is possible to form a general conclusion on the use of fullerenes in lubricants of various qualities. The maximum effect of reducing the friction coefficient, equal to $83-98 \%$, can be obtained with oils of an average level of tribological properties.

\section{Conclusions}

The physical phenomenon of the formation of an oil film containing fullerenes on the friction surface of tribosystems was further developed, which, in contrast to the known ones, takes into account the structural viscosity and structure of the formed film under the action of the electrostatic field of the friction surface. An increase in load significantly increases the structural viscosity of the gel structure, 13 - 20 times. Such an increase in the dynamic viscosity of the gel structure can be explained by the squeezing out of a viscous liquid under load and, thereby, a decrease in its content in the gel structure. The concentration of fullerenes in the base lubricant does not significantly affect the value of the dynamic viscosity of the aggregates in the composition of the liquid and the structure of the gel.

An increase in the tribological properties of the base lubricant medium reduces the value of the structural viscosity of the gel on the friction surface by a factor of 3 . At the same time, the concentration of fullerenes in the range of $0.5-1.5 \%$ does not have a large effect on these indicators. This phenomenon can be explained by the presence or absence of an additive package in the base lubricating medium. For those oils where the additive package is absent or present in an insignificant amount $E_{\text {spec }}=(1,8 \ldots 3,6) \cdot 10^{14} \mathrm{~J} / \mathrm{m}^{3}$, the introduction of a fullerene composition promotes the formation of clusters and micelles, which increase the structural viscosity and, consequently, form a film on the friction surface in the form of a gel structure. Conversely, if fullerenes are introduced into a base oil that contains a large and balanced additive package, where tribological properties are high $\left.E_{\text {spec }}\right\rangle(3,6-7,2) \cdot 10^{14} \mathrm{~J} / \mathrm{m}^{3}$, interaction at the molecular level does not occur. Fullerenes to a lesser extent will form stable aggregates in the form of micelles.

The effect of reducing the coefficient of friction, equal to $96 \%$, is typical for low and medium loads of operation of tribosystems and base lubricants with average values of tribological properties. With increasing loads or tribological properties of base oils, the effect of the use of fullerenes decreases.

\section{References}

1. Vojtov V. A., Kravcov A. G., and Tsymbal B. M. Evaluation of Tribotechnical Characteristics of Tribosystems in the Presence of Fullerenes in the Lubricant / FRICTION AND WEAR, 2020, Vol. 41, No. 6, 704710. DOI: 10.3103/S1068366620060197 [English]

2. Matviyenko V.N., Kirsanov Ye.A. Vyazkost' i struktura dispersnykh sistem // Vestnik Moskovskogo universiteta. Seriya 2. Khimiya. - 2011. - T.52. - № 4.- S. 243-276. [Russian]

3. Bibik Ye.Ye. Reologiya dispersnykh sistem. - L.: Izd-vo Leningradskogo un-ta, 1981. -172s. [Russian]

4. Reyner M. Reologiya / M. Reyner. // perev. s angl. pod red. E.I. Grigolyuka. - M.: Nauka, 1965. - 223s. [Russian]

5. Anurag Singh, Prashant Chauhan, Mamatha T. G. A review on tribological performance of lubricants with nanoparticles additives // Materials today: proceedings Volume 25, Part 4,2020, Pages 586-591 https://doi.org/10.1016/j.matpr.2019.07.245 [English]

6. Kravtsov A.G. Investigation of the structural viscosity of oil films on the friction surface with fullerene compositions. Problems of Tribology, Vol 26, No 1/99, 2021, pp. 13-19. https://doi.org/10.31891/2079-13722021-96-1-13-19 [English]

7. Kravtsov A.H. Rozrobka makroreolohichnoyi modeli relaksatsiyi napruzhen' v mastyl'niy plivtsi na poverkhni tertya pry nayavnosti fullereniv/ Problemy trybolohiyi. - 2018. - № 4. - S. 36- 40. [Ukraine]

8.Zakharchenko M.B. Yntehral'nyy parametr otsenky trybolohycheskykh svoystv smazochnykh materyalov // Zbirnyk naukovykh prats' Ukrayins'koyi derzhavnoyi akademiyi zaliznychnoho transportu. Tom 2. Kharkiv: UkrDAZT, 2015. - Vyp. 151. - S. 5- 10. [Russian] 
Кравцов А.Г. Залежності зміни структурної в'язкості мастильних плівок на поверхні тертя 3 фулереновими композиціями/

Дістало подальший розвиток фізичне явище формування масляної плівки 3 фулереновими композиціями на поверхні тертя трибосистем, яке, на відміну від відомих, враховує структурну в'язкість і структуру сформованої плівки під дією електростатичного поля поверхні тертя. Збільшення навантаження значно збільшує структурну в'язкість структури гелю, в 13 - 20 разів. Таке підвищення динамічної в'язкості структури гелю можна пояснити видавлюванням в'язкої рідини під навантаженням і тим самим, зменшення іiі змісту в структурі гелю. Концентрація фулеренів в базовому змащувальному матеріалі не робить істотного впливу на величину динамічного в'язкості агрегатів в складі рідини і структури гелю.

Збільшення трибологічних властивостей базового мастильного середовища знижує величину структурної в'язкості гелю на поверхні тертя в 3 рази. При цьому концентрація фулеренів в межах 0,5 $1,5 \%$ не робить великого впливу на дані показники. Дане явище можна пояснити наявністю або відсутністю пакета присадок в базовому мастильному середовищі. У тих олив, де пакет присадок відсутній або присутній в незначній кількості $E_{y}=(1,8 \ldots 3,6) \cdot 10^{14}$ Дж/м ${ }^{3}$, введення фулеренової композиції сприяє утворенню кластерів і мицелл, які збільшують структурну в'язкість, а отже і утворюють на поверхні тертя плівку у вигляді структури гелю. І навпаки, якщо вводити фулерени в базову оливу, яка містить великий і

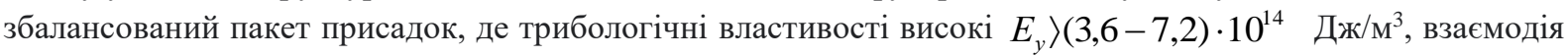
на молекулярному рівні не відбувається. Фулерени в меншій мірі будуть утворювати стійкі агрегати у вигляді міцел.

Ефект зниження коефіцієнта тертя, що дорівнює 96\%, характерний для малих і середніх навантажень експлуатації трибосистем і базових мастильних матеріалів із середніми значеннями трибологічних властивостей. При збільшенні навантажень або трибологічних властивостей базових олив, ефект від застосування фулеренів зменшується.

Ключові слова: фулерени; мастильна плівка; фулеренові композиції; структурна в'язкість; структура золю; структура гелю; електростатичне поле поверхні тертя; динамічна в'язкість 